\title{
P.Н. Пархоменко
}

\section{СВОБОДА И КОНСЕРВАТИЗМ В ОТЕЧЕСТВЕННОЙ ФИЛОСОФСКОЙ ТРАДИЦИИ}

Аннотация. Предметом исследования являются идеи Н.А. Бердяева, С.Л. Франка, П.Б. Струве, П.И. Новгородцева, И.А. Ильина - все эти философы были типичными представителями т.н. течения консервативного либерализма в России. Особое внимание уделяется рассмотрению развития идеи свободы в консервативном либерализме, поскольку именно мыслители консервативного направления обратили своё внимание на важную проблему соотношения политики и культуры, не освещённую в должной мере в либеральной политической философии. Методологией исследования является обращение к большому массиву недостаточно на сегодня изученных текстов и рукописей данных мыслителей. Основными выводами проведённого исследования является мысль о том, что развитие концепций реализации свободы индивида в государстве в отечественной политической философии шло в постоянном диалоге либеральных и консервативных установок. При этом зачастую либерализм и консерватизм не противопоставлялись друг другу, а идея свободы развивалась в рамках т.н. "консервативного либерализма». В истории политической мысли идее реализации свободы индивида в государстве, противостоял не консерватизм, а радикализм, тогда как консервативные и либеральные течения в России, скорее, дополняли друг друга.

Ключевые слова: свобода, консерватизм, философия, человек, общество, культура, либерализм, Россия, Запад, государство.

Abstract. The subject of this research is the ideas of N. A. Berdyaev, S. L. Frank, P. B. Struve, P. I. Novgorodtsev, I. A. Ilyin; all of these philosophers were typical representatives of so-called current conservative liberalism in Russia. Particular attention is paid to the development of the idea of freedom in the conservative liberalism, since it is the conservative thinkers who turned their attention to the important issue of the relationship between politics and culture, which was not adequately covered in the liberal political philosophy. The main conclusion of the study consists in the fact that the development of the concepts of realization of individual freedom in the state was in a constant dialogue between the liberal and conservative ideologies within the Russian political philosophy. At the same time, liberalism and conservatism are not opposed to each other and the idea of freedom was developing within the framework of the so-called "conservative liberalism". In history of political thought, the idea of realization of individual freedom in the state was not opposed by conservatism, but rather radicalism, while conservative and liberal movements in Russia complemented each other for the most part.

Key words: West, Russia, liberalism, culture, society, human, philosophy, conservatism, freedom, state.

Н.М. Карамзин, стоявший у истоков российской консервативной мысли в своих работах «Письма русского путешественника», «Письмо сельского жителя» и «0 древней и новой России» создал тот базис, опираясь на который, целая плеяда блестящих отечественных мыслителей создали уже свои собственные концепции политической философии консерватизма. Среди наиболее представительных мыслителей можно назвать, к примеру, И.В. Киреевского, А.С. Хомякова, Н.Я. Данилевского, К. Победоносцева, К.Н. Леонтьева. Применительно к теме данной статьи, особенно хотелось бы отметить идеи Н.А. Бердяева, С.Л. Франка, П.Б. Струве, П.И. Новгородцева, И.А. Ильина. Как отмечает В.Н. Жуков, все эти философы являются «типич- ными представителями наиболее оригинального пласта в русской философии естественного права консервативного либерализма» [1, с. 188].

Размышляя о развитии идеи свободы в отечественной философской традиции, необходимо отметить, что именно мыслители консервативного направления обратили своё внимание на важную проблему соотношения политики и культуры, не освещённую в должной мере в либеральной политической философии. Консервативные мыслители в России выступали против нивелирования культурных ценностей в западных либеральных странах и, тем самым, противопоставляли Россию Западу, правда, зачастую «забывая» о том факте, что в России культура была достоянием, главным 
образом, лишь интеллигенции и дворянства, а не широких слоёв населения. В конце XIX в. консерваторы обращают своё внимание на такие базовые ценности либерализма, как понятия свободы и равенства.

Так, К.П. Победоносцев (1827-1907) полагал, что главные идеи французской революции о свободе, равенстве, братстве устарели и нуждаются в переосмыслении: «Идеал, если он признан за таковой, при всей недостижимости в данный момент является своеобразным ориентиром в развитии общества, указывая ему направление. Общество не может двигаться вперед без идеалов - гражданских и нравственных. Этим и объясняется живучесть лозунгов революционной эпохи, давно превратившихся в «вечные истины». Идеал требует пусть постепенного и многотрудного, но приближения к себе. Однако, справедливо возражая против превращения «идеального закона» в политическую программу, Победоносцев совершенно отчуждает его от действительности, называя ложью и заблуждением» [2, с. 303].

Консервативные мыслители при этом выступали как против либеральных принципов по обоснованию свободы индивида, так и против идеи равенства в государстве. Так, В.П. Мещерский писал в своём «Дневнике», что идея всеобщего равенства совершенна чужда народу, где было развито чувство «здравомыслия». Другой консервативный мыслитель П.Е. Астафьев неприятие идеи всеобщего равенства объяснял особенностями русского национального характера, главной характеристикой которого можно было назвать врождённое равнодушие к социальным и политическим преобразованиям [3, с. 26-27]. Изучив тексты мыслителей консервативного направления, нетрудно заметить, что они зачастую отождествляли принцип либерального равенства с принципом уравнительности, развитым у идеологов народничества.

Л.А.Тихомиров в своей статье «Социальные миражи современности» [4, с. 296-297] писал о кризисе либерализма и об иллюзорности понятий свободы, равенства и братства, хотя стремление к свободе он считал коренным свойством каждого индивида. Необходимо отметить, что Победоносцев, Тихомиров и Григнмут пытались вывести состояние свободы человека «за пределы политики, рассмотрев её как состояние внутреннего мира человека, его идейного, религиозного и психологического настроя. Тихомиров соглашается с определением свободы Грингмутом как понятия «отрицательного», состоящего в «отсутствии стеснений». Стремление к свободе, законность которого консерваторы не отрицали, не должно, по их мнению, направляться на «внешние формы». Не стоит связывать понятие свободы с политическими правами и политическими учреждениями: обрести подлинную свободу можно, лишь ощутив её в самом себе, изменяя свой внутренний мир» [2, с. 304].

Подобная «деполитизация» понятия свободы была подвергнута резкой критике со стороны либералов, которые полагали, что помещая понятие свободы так «глубоко» во внутренний мир человека, консерваторы лишали понятие свободы своей ценности. В ответ на это Тихомиров подчёркивал, что права человека стоят выше, чем права гражданина, а либералы в своём стремлении вычленить понятие свободы как политическое понятие, смешивают воедино права человека как свободной личности и права гражданина как члена государства. Для лучшей критики требования законодательных гарантий реализации свободы в либерализме, Тихомиров начинает рассуждать о т.н. «неограниченной» свободе, которая может привести к анархии [5, с. 954-957], что было не совсем корректно по отношению к либеральной идеологии того времени в России.

П.Б. Струве в своих работах, опубликованных в сборниках «На разные темы» (1902), «Вехи» (1909), «Patriotica» (1911), говорил о необходимости создания в России правового государства, основанного на принципах т.н. консервативного либерализма. При этом Струве подчёркивал религиозные истоки либеральных идей и идеи свободы, берущих свои истоки в понятии свободы совести. Права и свобода личности, по его мнению, должны стоять выше посягательств коллектива. Также Струве подчёркивал взаимовлияние и взаимообусловленность сфер экономики («хозяйства» в его терминологии) и права - как экономика влияет на право, так и право, в свою очередь, меняет хозяйственную жизнь в государстве.

Рассуждая о роли хозяйственных отношений в жизни государства, Струве обращал внимание на наличие «иррациональной» составляющей в экономико-правовых отношениях, затрудняющей полную рационализацию этой сферы общества. Подобный иррационализм является следствием свободы человека и не может быть полностью устранён из социальной теории: «Свободная игра сингулярных человеческих воль самопроизвольно (спонтанно) рационализирует социально-экономические процессы» [6, с. 1]. Струве полагал, что стихийное начало анархической свободы индивидов организуется с помощью политической культуры - экономическая свобода человека дополняется политической культурой, способствующей лучшему раскрытию потенций человеческой свободы. 


\section{Философия и культура 7(103) • 2016}

Таким образом, в противовес воззрениям Победоносцева, Тихомирова и Григнмута, у Струве свобода индивида перестаёт носить чисто моральный характер и обретает своё политическое измерение. Более того, в качестве главнейшей задачи, стоящей перед Россией, Струве полагал необходимость создания правового государства, которое гарантировало бы для каждого члена общества соблюдение индивидуальных прав и свобод. Правовое государство должно основываться на трёх следующих принципах: взаимосвязи прав и обязанностей личности, личной годности и признания духовных начал власти и государства.

По замечанию И.Д. Осипова, идея личной годности индивида следовала из «консервативно-либеральной парадигмы социальной справедливости, понимаемой как создание равенства возможностей для всех в хозяйственной деятельности, и содержала сумму нравственно-религиозных и профессиональных качеств, требующихся от человека как гражданина и патриота» [7, с. 104105]. Сам Струве определял свободу личности так: «Если в идее свободы и своеобразия личности был заключён вечный идеалистический момент либерализма, то в идее личной годности перед нами великий реалистический момент либерального миросозерцания» [8, с. 203]. Таким образом, при объяснении механизма и возможности реализации человеческой свободы в государстве в политической философии Струве налицо соединение консервативных и либеральных установок, когда личная свобода индивида вырастает из нравственного и гражданского долга при условии наличия патриотически-государственного мышления.

Механизмы реализации человеческой свободы Струве развивает в рамках национально-государственной формы, которая понималась им как некое органическое и, прежде всего, духовно-национальное образование, которое не может быть полностью разложено на рациональные элементы и, поэтому, носит мистический, «божественно-космический» характер. В своей работе «Великая Россия: Из размышлений о проблеме русского могущества» Струве говорит о необходимости создания нового типа государственности, который бы опирался на свои исторические корни, на свои культурные традиции, на творческую деятельность всех патриотических сил в стране. Исторический опыт и культурные традиции способны укрепить «мистическую силу» политической власти в государстве: «Я разумею под чувством государственности [...] ощущение важности государства как некоей непререкаемой ценности, которую можно и должно любить, не рассуждая и даже не задумы- ваясь $[. .]$, признавая государство как творческую культурную силу, стоящую принципиально вне классов и над классами» [6, с. 211].

По мнению Струве, новый тип государственности в России призван предотвратить нарастание революционных процессов. Практическая реализация такого нового типа государственности могла быть достигнута путём постепенного приобщения к власти всех социальных слоёв общества, а также путём создания новых основ быта. Формирование нового типа политической культуры возможно лишь при условии увеличения степени свободы личности и гуманизации власти. «Утверждение свободы лица и демократизация процесса управления составляли нераздельный процесс, в котором огромное значение имели баланс, гармония между разными социальными силами, партиями и властями. Между провозглашением начал правового государства [...] и их осуществлением на практике лежит огромное расстояние, которое никакая личная воля победить не может» [7, с. 106].

Механизмом реализации человеческой свободы в государстве для Струве был строй конституционной монархии, который связывал воедино как свободное творчество прогресса и человеческой личности с преемственностью и традициями культуры и общества. По мнению ряда современных исследователей, консервативный либерализм Струве отличался этатизмом и прагматизмом, апологией государственной дисциплины и порядка: в некоторых случаях «индивидуально-ценностное начало в нём подчинялось нормативно-целому, и тем самым в определённой мере преодолевались рамки либеральной парадигмы, в которой ценность и норма, личное и общественное находятся в единстве» [7, c. 106]. Такова специфика взгляда на свободу индивида в российском консервативном либерализме.

Другой видный представитель консервативного либерализма в России П.И. Новгородцев в своей философии права разрабатывал проблему синтеза свободы и равенства в духе своего «социального либерализма». Новгородцев разграничивал нравственный и политический идеалы, а также отстаивал право индивида на свободный выбор определённой формы государственного устройства, которая отвечала бы его нравственному идеалу. В философии права Новгородцева соединились этическое учение Канта о личности с идеями правового государства и историческим подходом Гегеля к философии права. Новгородцев писал следующее: «Как особая сторона духовной жизни личности общественные формы являются неотъемлемой частью этой жизни. Они служат тем скрепляющим цементом, той зиждительной связью, без которой не 
может быть ни общественного строительства, ни индивидуального развития» [9, с. 202-203].

По сути Новгородцев выступал как против дуализма сущего и должного у Канта, так и против идеализма развития абстрактного духа Гегеля. Новгородцев исследовал конкретный правопорядок в государстве, основой которого является творческая сила национальной культуры. Важнейшей мыслью по обоснованию человеческой свободы в обществе была идея Новгородцева о том, что правовой идеал личности не является универсальным и абстрактным понятием - правовой идеал личности всегда должен рассматриваться вместе с национальным идеалом, культурой и традициями каждого конкретного государства.

Для Новгородцева механизмом реализации свободы индивида в государстве было следование принципам и нормам государственной жизни. «Антиномия личного и общественного, нравственности и политики, равенства и свободы должна была быть преодолена осознанием личностью того факта, что общество является конкретным взаимодействием индивидуальностей, а государство - гарантом гражданского мира и свободы личности, политической формой «свободы и необходимости», воплощённой в правовом государстве» [7, с. 114]. По мнению Новгородцева, государство представляет собой систему юридических отношений, психических взаимодействий индивидов и культурно-религиозных символов - посредством этих феноменов может быть выражено объективное начало каждого конкретного народа, которому индивиды подчиняются по своей собственной воле. Правовое государство даёт возможность для гармоничного сосуществования в нём разных религий, политических воззрений и интересов, национальностей и т.п.

Совершенствование политических и правовых механизмов правового государства идёт в направлении ограничения частного произвола посредством публично-правового регулирования частной жизни, централизованного перераспределения национального богатства, неукоснительное соблюдение принципов социальной справедливости: «Речь идёт в данном случае, очевидно, о том, чтобы обеспечить для каждого возможность человеческого существования и освободить от гнёта таких условий жизни, которые убивают человека физически и нравственно. И так как подобная забота относится прежде всего к тем, кто не может стать на твёрдую почву в жизненной борьбе, кто нуждается в помощи и поддержке, то обеспечение права на достойное человеческое существование ближайшим образом имеет в виду лиц, страдающих от экономической зависимости, от недостатка средств, от неблагоприятно сложившихся обстоятельств» $[10$, с. 46].

Сегодня мы можем отметить, что концепция правового государства, представленная Новгородцевым, выходит за рамки западного этатизма и близка к распространённому в отечественной интеллектуальной традиции консерватизма пониманию государства, построенного на началах справедливости и правды. «Этический подход к политико-правовому идеалу, проявленный в трудах Новгородцева, Кистяковского, Гессена, Франка и др., сделал возможной критику правового формализма, т.е. содержательного неравенства таких прав, которые по букве закона равны. По существу в данном случае речь шла о социальном государстве, устраняющем как юридические препятствия к развитию свободы, так и материальные преграды для её проявления» [7, с. 115]. Именно идея правового государства давала ориентиры для достижения идеала свободы индивида во время буржуазных революций в Европе XVII-XVIII вв. Весь комплекс понятий свободы, равенства, братства, народной воли укреплял идею правового государства, а также идею о возможности достижения гармонии между личностью и государством, в основе которой лежал западный индивидуализм.

По мнению Новгородцева, эволюция концепций западного индивидуализма шла по двум основным направлениям: одно отстаивало идею свободы, при которой «требование свободы, последовательно проведённое», приводило к «протесту против равенства, против уравнивающей демократической культуры» [11, с. 235]. Другое направление утверждало идею «единой и равной для всех культуры», когда требование равенства становилось основанием к «протесту против свободы, в смысле своеобразного и оригинального развития индивидуальности» [11, с. 235]. Эти два направления сменились новым неолиберальным подходом эпохи XIX - начала XX в., стремившимся описать идею взаимных прав и обязанностей между человеком и государством, опираясь на приоритет правозаконности по отношению к сфере политики. По мнению Новгородцева, государство в качестве своей основной задачи имеет задачу достижения равенства и свободы для всех членов общества.

С.Л. Франк является одним из самых ярких и репрезентативных представителей течения консервативного либерализма в России - его либеральнодемократический идеал свободы «густо замешан на религии. Возникает ощущение, что описываемый философом строй представляет собой завуалированную теократию. По большей части либеральные ценности Франк выводит не из жизни, а из христи- 


\section{Философия и культура 7(103) • 2016}

анских догматов, обосновывает их не аргументами из экономики, политики и истории, а ссылками на Библию» $[12$, с. 196]. Свои основные сочинения по социальной и политической философии Франк пишет и публикует в основном в эмиграции: это изданная в 1925 г. в журнале «Путь» статья «Религиозные основы общественности», сборник статей «Я и мы» (Прага, 1925), работы «Введение в философию» (Берлин, 1923), «Смысл жизни» (Париж, 1926), «Личная жизнь и социальное строительство» (Париж, б.г.), и, наконец, итоговая систематическая работа по социально-политической философии «Духовные основы общества. Введение в социальную философию» (Париж, 1930).

Помимо идеи свободы, главными системообразующими понятиями политической философии и теории государства для Франка выступают понятия служения и солидарности, которые совместно образуют «триединство» принципов политической жизни. Следуя церковной догматике, на первое место в своей политической теории Франк ставит понятие или начало служения - причём именно в ортодоксальном смысле слова как служение человека богу. По его мнению, индивид не может обладать собственной волей, а является лишь «проводником» на земле воли бога - в этом можно усмотреть специфическое понимание идеи свободы индивида, развитое в консервативной мысли Франка. Примат религии, служения и соборности определяет и отношение Франка к гражданским правам и свободам человека.

Таким образом, при рассмотрении понятия свободы индивида, Франк ставит на первое место понятие обязанности, а не права на совершение свободных поступков. Отсюда выводится вторичность гражданских прав и свобод по отношению к главной задаче человека - служения богу. Позитивным моментом подобной теории гражданского общества, по мнению Франка, является снятие конфликта разнообразных интересов в обществе, а также оппозиции общества и личности, путём замены их «гармонией обязанностей».

Поэтому и другое важное понятие политической теории общества Франка - понятие солидарности - также выводится им из религиозной догматики: «Система нравственных отношений и морального миросозерцания определяется двумя основными мотивами, которые выражены в двух евангельских заповедях любви к Богу и любви к ближнему. Существуют две принципиально различные области нравственности, из которых одна определяет отношение человека к Богу или высшей святыне, другая - отношения людей между собой. [...] Моральные отношения между людь- ми основаны на принципе равноправия (возлюби ближнего, как самого себя). Принцип этот состоит в устранении всякого неравенства, всякого преимущества “я” перед “ты”» [12, с. 251-252].

В своих работа Франк критикует как отвлечённый индивидуализм или социальный атомизм античности у Эпикура, так и отвлечённый коллективизм или универсализм, берущий свои истоки ещё в философии Платона и Аристотеля. На протяжении развития социально-политических учений в истории человечества эти два подхода постоянно соперничали друг с другом, вплоть до широкого распространения универсализма в современных либеральных и демократических учениях Г. Спенсера, Э. Дюркгейма, О. Шпанна. С другой стороны, социализм опирается на социальный атомизм и «требует принудительного “обобществления”, как бы насильственно внешнего сцепления или склеивания в одно целое частиц общества - отдельных людей» [13, с. 332].

Главным недостатком обоих этих течений политической мысли является отвлечённая абсолютизация одного из понятий - свободы или солидарности, тогда как эти понятия в политической теории и практике должны не конкурировать, а дополнять друг друга. По его мнению, общество должно опираться одновременно как на свободу индивидуального «я», так и на солидарность, внутреннее единство «мы»: «соединить эти эти два начала мешает то, что они являются противоположными друг другу, каждое стремится утвердить своё господство за счёт другого. Начало солидарности рассматривает всякую индивидуальную свободу как угрозу своему бытию; начало свободы видит в общественном единстве стремление к уничтожению себя. Поэтому либерализм и демократизм, “права человека" и “воля народа" постоянно находятся в конфликте» [14, с. 26-27]. Этот конфликт может быть разрешён лишь с помощью начала служения, о котором уже было сказано выше.

Франк выступал против экстремизма и революционных преобразований в политике. Главными конституирующими принципами в обществе должны быть принципы доверия и уважения другого человека - эти принципы могут быть достигнуты с помощью создания в государстве разнообразных объединений, малых союзов и т.п., способных лучше всего сплотить индивидов и способствовать развитию их разнообразных интересов для «углубления» последних «непротиворечивым образом». Такая политическая структура государства означает поддержку и развитие «живого человеческого общения» как среди населения, так и в государственных эшелонах власти - правительстве, думе, судах. 
Наконец, третье важное понятие политической философии Франка - понятие свободы - призвано раскрыть саму сущность личности человека. Также, как и два предыдущих понятия политической философии Франка - служения и солидарности - понятие человеческой свободы раскрывается с помощью религии как обретения бога и жизни в боге. «Отказ от свободы есть духовное самоубийство, уничтожение свободы в другом человеке также означает его гибель. Свобода - это источник развития общества, никакой насаждаемой дисциплиной нельзя заставить общество развиваться и двигаться вперёд» [11, с. 197]. Своеобразие трактовки идеи свободы индивида у Франка заключается в том, что он напрямую связывает объём личных и политических свобод индивида с развитием государства, его политической зрелости, выражающейся в ответственном использовании идеи свободы. Именно такая установка может позволить избежать возникновения анархии, равно как и появления и развития радикальных и деспотических моделей государственного устройства. В полном объёме человек может обладать только свободой совести, а идея гражданских прав человека должна быть обязательно увязана с принципами служения богу и идеей солидарности [15, с. 117].

Помимо идей служения, свободы и солидарности в политической жизни государства, по мнению Франка, также важны такие понятия как консерватизм и творчество. Консерватизм у Франка соотнесён с понятием соборности, столь популярным в русской религиозной философии. Соборное единство не может уничтожить свободу индивидуальности и значение личности: целое объединяет гармоничным образом все свои части, присутствует в каждой из частей и образует жизненное содержание самой личности.

«Существенной чертой соборности как внутреннего ядра общественности Франк называет «сверхвременность», имея в виду то, что как в социальном целом, так и в памяти и жизни отдельного человека прошлое не исчезает, а продолжается в настоящем, и эта непрерывность обеспечивает обществу устойчивость и жизненность. Этот традиционализм [...] есть не слепое поклонение прошлым формам жизни [...], а благоговение именно перед сверхвременным единством истории как богочеловеческого процесса, перед вечными началами, лежащими в основе общественной жизни» [14, c. 30]. Консерватизм объединяет в единое целое прошлое, настоящее и будущее в обществе и в политике, а своё выражение находит в монархической форме правления. По мнению Франка, носителем традиций и преемственности является общество в его целостности, а эквивалентом изменчивости и творческой активности выступает отдельная личность, её индивидуальность и свободная воля.

Что касается оценки демократии как политической формы правления, то в своих работах «Философские предпосылки деспотизма», «Демократия на распутье» и некоторых других Франк выступает против западной традиции демократии, упрекая её в том, что она отдаёт власть и руководство обществом в руки «неразумной, слепой и одержимой страстями толпы». Философ выделяет следующие виды демократии:

1) власть толпы - как это было, к примеру, в России во время разгула народного движения: «Под “демократией” в этой связи нельзя разуметь какой-либо формы правления или государственного устройства. [...] Русская революция есть демократическое движение в совершенно ином смысле: это есть движение народных масс, руководимое смутным, политически не оформленным, по существу скорее психологически-бытовым идеалом самочинности и самостоятельности» [13, с. 274];

2) «деспотическая демократия» или демократия якобинского типа представляет собой по сути деспотизм большинства, который в итоге может привести уже к деспотизму немногих или же одного - в качестве примеров Франк приводит «демократическую» власть одной партии в советской России;

3) далее следует либеральная демократия, развитая в западном либерализме и которая оценивается Франком как наиболее совершенная форма демократии, хотя этот тип демократии имеет и свои собственные недостатки;

4) последний тип демократии Франк обозначает термином христианской или духовной демократии, разработкой основных контуров которой занимался он сам: «Демократия может осуществлять религиозный идеал народовластия как всенародного свободного строительства высшей правды на земле. Для этого идеала власть народа есть не самоуправство, не самодавлеющее хозяйничанье народа, не ведающего узды для своих вожделений, а такое же бескорыстное, самоотверженное, ответственное служение высшей правде, каким должна быть всякая власть. Лишь на этом пути возможно то гармоническое сочетание личной свободы с подчинением власти, вне которого неосуществим правовой порядок жизни» [13, с. 165].

Главной ценностью демократии является не власть всех, а то что демократия есть свобода всех«смысл демократии преимущественно отрица- 


\section{Философия и культура 7(103) • 2016}

тельный: демократия означает освобождение от опеки, уничтожение привилегий немногих на господство, отмену различия между “активными" и “пассивными” гражданами. Истинное значение демократии состоит не в передаче власти в руки всех или большинства, а в ограничении каждой индивидуальной воли волею всех остальных членов общества. Поэтому, если демократия, основанная на свободе, есть наилучшая из возможных форм политического устройства, то демократия якобинская или основанная на деспотизме должна быть признана наиболее несостоятельной его формой» [12, с. 262].

Также в своей статье «De profundus» Франк подчёркивал важность развития такого типа демократического устройства общества в рамках своей национальной культуры и менталитета населения. По его мнению, истинная демократия должна опираться на сверх-индивидуальное и соборное начала, когда идея свободы индивида должна быть ограничена идеей служения - именно так в политической теории можно гармоничным образом соединить идеи государства и гражданского общества.

Наконец, последний из представителей течения консервативного либерализма в отечественной философской мысли, представленного в данном обзоре, И.А. Ильин в своих многочисленных философских трудах всегда отстаивал национальные интересы России, а также подчёркивал ценность и самобытность русской культуры. Причём, если социальную философию Бердяева, Франка, Струве и Новгородцева можно охарактеризовать как, условно говоря, «консервативный либерализм», то воззрения Ильина - это, скорее, «либеральный консерватизм», позиции которого близки идеям раннего Чичерина: «Поскольку Ильин развивает теорию естественного права, отстаивает идею прав человека и рыночной экономики, ценности правового государства и господство права в общественной жизни, его следует отнести к авторам либеральной ориентации. Но именно консерватизм является ведущим компонентом его политических воззрений. Если подавляющее большинство представителей консервативного либерализма в той или иной степени тяготели к идеологии и практике кадетизма, то Ильин всегда стоял на обочине политической жизни и в России, и в эмиграции» [11, с. 211].

Одним из важнейших понятий философии права Ильина была т.н. идея «нормального правосознания»: «Понятно, наконец, что и философ права должен найти свой особый опыт и предмет и вступить с ним в непосредственное исследовательское общение; а для этого он должен выносить верный опытный акт и систематически осуществлять его. Этот акт можно было бы обозначить как здоровое и нормальное правосознание» [16, с. 367]. Так, уже в своей первой научной работе «Понятие права и силы. Опыт методологического исследования» (1910) Ильин пытается увязать нормативное понятие права с вопросом о силе как реальной категории политики. При этом он не ставил цели «дать собственное определение права, полагая, что решение этого вопроса требует особого рассмотрения, он стремился определить право как норму, как “индивидуальное и социальное переживание”. На основе принципа методологического плюрализма он ставил вопрос с "общеюридической точки зрения” и отвлекался от тех постановок, которые она получает в отдельных юридических дисциплинах» $[17$, с. 201].

Одной из главных заслуг социально-политической философии Ильина были его размышления о происхождении, сути и путях преодоления тоталитарных тенденций в политике. В своей социальной философии Ильин разделял идеи Гегеля о единстве морального и правового сознания, однако его самого интересовало, прежде всего, «духовное» осмысление социально-политической жизни и философии права и государства: «Сквозь все страдания мира восстаёт и загорается древняя истина и зовёт людей к новому пониманию, признанию и осуществлению: жизнь человека оправдывается только тогда, если душа его живёт из единого, предметного центра, движимая подлинною любовью к Божеству как верховному благу. Эта любовь и рождённая ею воля - лежат в основе всей, осуществляющейся духовной жизни человека, и вне её душа блуждает, слепнет и падает. [...] Это объясняется самою природою духа: он есть та творческая сила души, которая ищет подлинного знания, добродетели и красоты, и созерцая Божество как реальное средоточие всякого совершенства, познает мир для того, чтобы и осуществить в нём Его закон как свой закон» [18, с. 312]. Исходя из такого понимания предмета, методологии и задач социальной философии Ильин формулирует три базовых закона человеческого общежития:

- закон «духовного достоинства» говорит о важности духовно-личностного измерения личности при рассмотрении гражданских, нравственных и религиозных сфер жизни общества;

- закон «автономии» разъясняет диалектическую связь понятий свободы и ответственности при реализации прав личности. При этом Ильин подчёркивает, что индивид может сохранить и реализовать свои гражданские права лишь следуя своей осознанной внутренней 
потребности по исполнению своих обязанностей в государстве - только так каждый член общества может стать полноценным субъектом права;

- закон «взаимного признания» означает необходимость взаимного уважения между гражданами и их пиетета по отношению к институтам гражданского общества.

Нетрудно заметить, что подобная трактовка теории государства и права представляет своеобразный синтез идей западного либерализма с консервативным и религиозным пониманием права и государства, столь хорошо развитым в отечественной философии конца XIX - середины XX вв.

Рассуждая о человеческой природе, Ильин подчёркивал её двойственность - наличие душевного и телесного начал, откуда он делал вывод о «двойственности норм его [человека] поведения. Эти две группы норм, - морали и права, будучи тесно связанными между собой, но принципиально несводимыми друг к другу, - обретают в своём практическом бытовании общий вектор требований, трактуемых как справедливость» [20, с. 15]. При этом источником норм права является внешний авторитет в виде социальных норм, выработанных в обществе для всех его членов; источником же морали является внутренний голос совести и обращённость к богу. Соответственно, следование правовым нормам - следствие предписания, тогда как следование нормам морали есть внутренняя потребность человека.

Отсюда и понимание идеи свободы у индивида - это гармоничное и согласованное признание и функционирование моральных и правовых норм общества. Наибольшей свободы, по мнению Ильина, человек может достигнуть лишь полностью «растворившись» в других людях как духовном целом. Здесь мы видим как следование идее соборности в русской религиозной философии, так и определённый отсыл к феноменологии духа Гегеля.

В социальной философии Ильина традиционно либеральные понятия правосознания и законопослушания соединены с консервативными понятиями нравственности и религиозности - только соединение либерализма и консерватизма способно создать правовое государство, совместимое с идеалами «Царства божия» на земле. «Либерализм методов в социальном и политико-правовом плане гармонизируется с консерватизмом конечных целей мета-истории, ещё раз подводя к мысли о политико-культурной и мировоззренческой синтетичности Ильина как политического философа. Не меньшей синтетичностью в подобном контексте представляются и его собственно философские и историософские взгляды, причудливо совмещавшие гегельянство, неогегельянство и славянофильство» [20, с. 16].

Размышляя об идее свободы индивида, Ильин говорит о внешней и внутренней свободах. В основе идеи свободы лежат не экономические или же политические требования, а глубинная потребность человека верить в бога, его нравственные и религиозные чувства. Именно свобода придаёт смысл человеческому существованию, даёт силы для любви в широком смысле слова, равно как и для творчества. Под внешней свободой Ильин понимает отсутствие внешней детерминированности и принуждения в решении человека прийти к богу. «Внешняя свобода - это свобода веры, воззрений и убеждений, в которую другие люди не вправе насильственно вмешиваться, то есть это свобода от принуждений и запрета, от грубой силы, угрозы и преследования. Такая свобода является отрицательной, но духовная любовь и личные убеждения [...] не могут создаваться путём запретов и угроз. [...] Духовное единство людей может возникнуть только тогда, когда каждый отдельный человек духовно и религиозно самостоятелен и индивидуален, имеет в себе источник духовного опыта» [17, с. 212].

Внешняя свобода призвана обеспечить внутреннее освобождение индивида от тёмных побуждений своей собственной души - страхов, страстей, грехов и соблазнов, поскольку лишь внутренне свободный человек способен к постижению истинных императивов должного поведения, с помощью которых достигается понимание необходимости самоограничения и убеждённого принятия власти, на основе которых создаётся гармоничное общество.

Что касается понятия политической свободы, являющейся результатом развития внешней и внутренней свобод, то она предполагает «гораздо большую зрелость, чем свобода внутренняя, так как если последняя касается самого человека, то свобода политическая даёт ему право влиять на дела других лиц. Установление подлинной политической свободы возможно только на основе свободы внутренней, принимать участие в политических делах могут лишь люди, обретшие в душе бога» [11, с. 212]. Внешняя свобода необходима человеку для того, чтобы он мог себя внутренне освободить для того, чтобы после этого принять на себя ответственность за принятие политических решений: «Политическая свобода по силам только тому, кто или завершил своё освобождение или кто находится в процессе внутренней борьбы за него, понимая его драгоценность, обязательность и ответственность» [16, с. 176]. 


\section{Философия и культура 7(103) • 2016}

Результатом выраженной религиозной направленности понимания идеи свободы индивида становится и идеал политического устройства государства - в понимании Ильина это абсолютная монархия, которая является выразителем воли народа. При этом республика как политический строй «растворяет» государственную власть в коллективе - механическом конгломерате безличных индивидуумов. Культ индивидуализма и критическое отношение к власти в республиканизме имеют своим следствием необходимость установления эффективного контроля над властью, что оценивается Ильиным негативно. По его мнению, формальность западной демократии и отсутствие опоры на религию и вековые национальные традиции делают возможным там приход к власти несамостоятельных и уклончивых «нырял», пекущихся лишь о своей собственной материальной выгоде. А такая практическая устремленность республиканизма в политике как дифференциация власти, постоянное стремление к новаторству и радикализму, в конечном итоге приводят к федерализации страны с последующим распадом государства и возникновением состояния анархии.

Поэтому можно сказать, что критика Ильиным классических форм западной демократии и индивидуалистического понимания идеи свободы сводится к традиционным в русской религиозно-консервативной политической философии мотивам - а именно к указанию на опасность вырождения крайних форм индивидуализма западного толка в анархию. Тем не менее, Ильин настоятельно подчёркивал, что «народ, лишённый искусства свободы, будет настигнут двумя классическими опасностями: анархией и деспотизмом».

Также, в традиционном ключе Ильиным критикуется как принцип всеобщего избирательного права, который даёт доступ к власти «черни», так и принцип плюрализма политических партий в государстве. По его мнению, партийный плюрализм носит формальный характер, делая ставку не на самостоятельно мыслящих людей, а на бездумных партийных функционеров и карьеристов - партии сознательно ограничивают себя рамками своих программ и подавляют, тем самым, свободу мысли, а разделение партиями общества на «своих» и «чужих» может привести государство к состоянию гражданской войны [21, с. 33-35]. Вместо формальной и индивидуалистической демократии Ильин выдвигает концепцию «органической» или «творческой» демократии, имея в виду при этом авторитарно-аристократический строй абсолютной монархии особого типа, сходного с концепцией демократического государства, которое развивали евразийцы.
В своей социальной философии Ильин выступал против обвинений русской правовой и культурной традиции в «недоразвитости», правовом нигилизме, опорой на религиозные догматы и идеологию соборности. По его глубокому убеждению, русское право и правоведение должны уберегать себя от «западного формализма, от самодовлеющей юридической догматики, от правовой беспринципности, от релятивизма и сервилизма. России необходимо новое правосознание, национальное по своим корням, христиански-православное по своему духу и творчески содержательное по своей цели. Для того, чтобы создать такое правосознание, русское сердце должно увидеть духовную свободу, как предметную цель права и государства, и убедиться в том, что в русском человеке надо воспитать свободную личность с достойным характером и предметною волею» [22, с. 121].

Таким образом, Ильин противопоставляет свою политическую философию идеологии набирающего в то время в России силы коммунизма со спекулятивно используемыми коммунизмом понятиями справедливости, братства и диктатуры пролетариата. Коммунистической идеологии он противопоставляет понятия «правовой свободы» и «предметного правосознания», которые он разработал в своей теории права и государства.

Хотелось бы отметить, что социальная философия Ильина подверглась резкой критике со стороны Бердяева - особенно идеи Ильина об отношениях между церковью и государством. В своей социальной философии Ильин выступает с позиций юриста и философа в стремлении прояснить религиозно-этические и юридические основания правосознания индивида, тогда как Бердяев критикует подобную позицию Ильина со своей позиции религиозного мыслителя: «Ильину совершенно чуждо христианское разграничение двух порядков бытия и двух миров, мира духовного и мира природного, мира иного и “мира сего”, мира благодати и порядка природы, царства Божиего и царства Кесаря» [23, с. 465]. Бердяев выступает против подобного «обоготворения» государства Ильиным и подчёркивает лишь прагматическую роль государства по ограничению проявлений зла в мире и пресечению деяний злой воли, ведь государство по природе своей «совершенно бессильно побеждать зло и такого рода задачи не имеет» [23, c. 466] - эти задачи являются исключительно прерогативой церкви.

Кроме этого, Бердяев выдвигал обвинения Ильину за его слишком «нормативное» понимание идеи свободы индивида в смысле «принудительной организации добра в мире через государство». 
Отсюда им делался вывод о том, что для Ильина сам человек в совокупности своих реальных недостатков «не имеет никакого значения. Любовь же, по Бердяеву, существует к единичному человеку с “индивидуально неповторимым именем" и его недостатками» [17, с. 217]. Нетрудно заметить, что у Ильина и Бердяева обнаруживается принципиально разное отношение к церковной догматике: если Ильин рассматривает церковь и государство как единое целое в решении задач по борьбе со злом, то Бердяев строго разделяет сферы земного и небесного, царства Божия и царства Кесаря. Ильин пытается показать духовное «измерение» в праве и политической философии для того, чтобы смягчить существующие противоречия между индивидом и государством, внешней и внутренней свободой личности. Его категория «нормального правосознания» призвана соединить нравственнодуховный мир индивида и абстрактные категории правового государства.

У Бердяева, напротив, идея свободы выражает уникальность бытия человека и его экзистенциальную сущность. Такое понимание идеи свободы принципиально отлично от свободы в законе и праве, свободы как политической категории в социальной философии и философии права, представленной в работах Ильина. В данной полемике между Ильиным и Бердяевым представлена вся специфика философии права христианства, в которой поставлена «сложнейшая проблема духовного преображения общества и человека. Соответственно выработана и формула для её решения: «неслиянно и нераздельно». В её рамках определяются религиозные, моральные и социальные аспекты взаимоотношения церкви и государства, закона и благодати. Но очевидно, что в ситуации, когда государство признаётся относительной ценностью, трудно создавать реальное общество, в котором важную роль играют нормативные, юридические начала» [17, с. 220].

Резюмируя особенности социальной философии Ильина и его понимания идеи свободы индивида, можно отметить, что его философская мысль пыталась соединить традиции классического западного либерализма с русской культурной и религиозной интеллектуальной традицией, столь ярко развитой у нас в стране на рубеже XIX-XX вв. Ценность правовых норм для Ильина состояла не в создании формальных юридических основ правового общества, эффективно защищающих индивидуальные и гражданские права личности, а в наполнении понятий свободы, демократии и права религиозным, нравственным и психологическим содержанием. По верному замечанию
В.Н. Жукова, Ильин в своей социальной философии развивает традиции «русской средневековой мысли и славянофильской идеологии, стремящейся отождествить право и правду, соединить право с религией и моралью, заменить конкретный формально-юридический механизм абстрактными идеалами всеобщей любви, соборности и т.п. Ильин явно пренебрегает формальной стороной права и политико-юридическими гарантиями в организации государства, отдавая предпочтение моральным и религиозным регуляторам. [...] в правовом государстве Ильина основной упор делается не на право, а на мудрость и религиозность авторитарного монарха» $[1$, с. 216]. Следует отметить, что подобная опора на мораль и религию во многих отечественных социально-философских теориях оценивается Жуковым негативно как правовой нигилизм. Однако как раз эта особенность и составляет во многом своеобразие русского понимания идей свободы, демократии и либерализма, которые даже в своём «классическом» западном варианте не свободны от недостатков и противоречий.

Рассматривая социальную и политическую философию Ильина из сегодняшней исторической перспективы, трудно не заметить, что его стратегия принципиального непредрешенчества относительно конкретных форм пост-тоталитарного устройства государства выдавала в нём «политического консерватора, тогда как предполагаемый путь преодоления коммунизма (основанный на ценностях свободы, достоинства личности и уважении к праву) - либерала в русской традиции, основанной на религиозном представлении о месте человека в обществе, его обязанностях по отношению к социуму и к собственной духовной природе, на неотчуждаемом праве политического и духовного выбора (при принципиальном главенстве последнего)» [20, с. 36-37].

В философской мысли Ильина очень выпукло проявились непростые отношения между идеями о свободе, выработанными в западном либерализме и традиционными представлениями русского консерватизма, выраженными в известной формуле, высказанной министром просвещения графом С.С. Уваровым «самодержавие, православие, народность». Философ полагал, что «в национальном чувстве - источник духовного достоинства, национального, а чрез то - и своего, личного». И хотя сам Ильин в своих работах практически не употреблял термина «консерватизм», в целом его социальнофилософская концепция подразумевала консервативное обновление государства в смысле отказа от революционных преобразований общества с опорой на вековые традиции и национальные куль- 


\section{Философия и культура $7(103) \cdot 2016$}

турные особенности России. Поэтому не случайно сегодня социально-философские идеи И.А. Ильина так востребованы в отечественной политологии и политике, взявшей курс на т.н. «новый консерватизм» как практическую максиму современной российской политики.

В заключении можно отметить, что развитие концепций реализации свободы индивида в государстве в отечественной политической философии шло в постоянном диалоге либеральных и консервативных установок. При этом зачастую либерализм и консерватизм не противопоставлялись друг другу, а идея свободы развивалась в рамках т.н. «консервативного либерализма» [24, с. $34 ; 25$, c. 22]. В истории политической мысли идее реализации свободы индивида в государстве, противо- стоял не консерватизм, а радикализм, тогда как консервативные и либеральные течения в России, скорее, дополняли друг друга.

Важно ещё раз зафиксировать то, что у нас в стране политическая философия консерватизма была связана как с развитием европейского консерватизма, так и с ассимиляцией особенностей отечественной культуры и религиозного сознания. При этом нельзя обойти вниманием и тот факт, что в консерватизме проекты реализации свободы индивида в государстве получили очень сильное развитие: так, как было показано выше, И.А. Ильин и С.Л. Франк разрабатывали «творческий, духовный консерватизм, в котором ценность охранения [была] синтезирована с ценностью духовной свободы и творчества личности» [17, с. 108].

\section{Список литературы:}

1. Жуков В.Н. Русская философия права: от рационализма к мистицизму. М., 2013. 400 с.

2. Русский консерватизм XIX столетия: идеология и практика / Ред. В.Я. Гросул, Г.С. Итенберг и др. М., 2000. 439 с.

3. Астафьев П.Е. Национальность и общечеловеческие задачи. М., 1890. 220 с.

4. Тихомиров Л.А. Социальные миражи современности // Русское обозрение. 1891. № 7. С. 290-300.

5. Тихомиров Л.А. К вопросу о свободе // Русское обозрение. 1893. № 12. С. 952-960.

6. Струве П.Б. Дух и слово: статьи о русской и западноевропейской литературе. Париж, 1981. 320 с.

7. Осипов И.Д. Философия русского либерализма (XIX - начало XX вв.). СПб., 1996. 191 с.

8. Струве П.Б. На разные темы // Русская мысль. 1909. № 1. С. 201-215.

9. Новгородцев П.И. Об общественном идеале. М., 1991. 512 с.

10. Новгородцев П.И. Право на достойное человеческое существование // Новгородцев П.И., Покровский И.А. 0 праве на существование. СПб., 1911. 144 с.

11. Новгородцев П.И. Введение в философию права. Кризис современного правосознания. М., 1996.268 с.

12. Франк С.Л. Философские предпосылки деспотизма // Опыт русского либерализма. Антология / Под ред. М.А. Абрамова. М., 1997. 480 с.

13. Франк С.Л. Избранные труды. М.: РОССПЭН, 2010.663 с.

14. Роцинский С.Б. Семен Людвигович Франк // Франк С.Л. Избранные труды. М.: РОССПЭН, 2010. 663 с.

15. Франк С.Л. Духовные основы общества. М., 1992. 510 с.

16. Ильин А.И. Путь к очевидности. М., 1993. 430 с.

17. Осипов И.Д. Философия политики и права в России. СПб., 2014. 259 с.

18. Ильин И.А. Теория права и государства. М., 2008. 550 с.

19. Ильин И.А. О сущности правосознания // Ильин И.А. Теория права и государства. М., 2008. 550 с.

20. Филиппова Т.А. Иван Алесандрович Ильин // Ильин И.А. Избранное. М., 2010. 726 с.

21. Ильин И.А. Собр. соч.: в 10 т. М., 1993-2000. Т. 2. 493 с.

22. Ильин И.А. О русском национализме. М., 2006. 150 с.

23. Бердяев Н.А. Кошмар злого добра (О книге И. Ильина «О сопротивлении злу силою») // Путь. Орган русской религиозной мысли. № 4. Июнь-июль 1926. М., 1992. С. 462-474.

24. Приленский В.И. Опыт исследования мировоззрения ранних русских либералов. Ч. 1. М.: ИФРАН, 1995. 311 с.

25. Леонтович В.В. История либерализма в России. 1762-1914. М., 1995. 548 с.

\section{References (transliterated):}

1. Zhukov V.N. Russkaya filosofiya prava: ot ratsionalizma k mistitsizmu. M., 2013. $400 \mathrm{~s}$.

2. Russkii konservatizm XIX stoletiya: ideologiya i praktika / Red. V.Ya. Grosul, G.S. Itenberg i dr. M., 2000. 439 s.

3. Astaf'ev P.E. Natsional'nost' i obshchechelovecheskie zadachi. M., 1890. $220 \mathrm{~s}$.

4. Tikhomirov L.A. Sotsial'nye mirazhi sovremennosti // Russkoe obozrenie. 1891. № 7. S. 290-300.

5. Tikhomirov L.A. K voprosu o svobode // Russkoe obozrenie. 1893. № 12. S. 952-960.

6. Struve P.B. Dukh i slovo: stat'i o russkoi i zapadnoevropeiskoi literature. Parizh, 1981. $320 \mathrm{~s}$.

7. Osipov I.D. Filosofiya russkogo liberalizma (XIX - nachalo XX v.). SPb., 1996. $191 \mathrm{s.}$

8. Struve P.B. Na raznye temy // Russkaya mysl'. 1909. № 1. S. 201-215.

9. Novgorodtsev P.I. Ob obshchestvennom ideale. M., 1991. $512 \mathrm{s.}$

10. Novgorodtsev P.I. Pravo na dostoinoe chelovecheskoe sushchestvovanie // Novgorodtsev P.I., Pokrovskii I.A. O prave na sushchestvovanie. SPb., 1911. 144 s. 
11. Novgorodtsev P.I. Vvedenie v filosofiyu prava. Krizis sovremennogo pravosoznaniya. M., 1996. $268 \mathrm{s.}$

12. Frank S.L. Filosofskie predposylki despotizma // Opyt russkogo liberalizma. Antologiya / Pod red. M.A. Abramova. M., 1997. $480 \mathrm{~s}$.

13. Frank S.L. Izbrannye trudy. M.: ROSSPEN, 2010. 663 s.

14. Rotsinskii S.B. Semen Lyudvigovich Frank // Frank S.L. Izbrannye trudy. M.: ROSSPEN, 2010. 663 s.

15. Frank S.L. Dukhovnye osnovy obshchestva. M., 1992. $510 \mathrm{~s}$.

16. Il'in A.I. Put' k ochevidnosti. M., 1993. 430 s.

17. Osipov I.D. Filosofiya politiki i prava v Rossii. SPb., 2014. $259 \mathrm{~s}$.

18. Il'in I.A. Teoriya prava i gosudarstva. M., 2008. $550 \mathrm{~s}$.

19. Il'in I.A. O sushchnosti pravosoznaniya // Il'in I.A. Teoriya prava i gosudarstva. M., 2008. $550 \mathrm{~s}$.

20. Filippova T.A Ivan Alesandrovich Il'in // Il'in I.A. Izbrannoe. M., 2010. 726 s.

21. Il'in I.A. Sobr. soch.: v 10 t. M., 1993-2000. T. 2. 493 s.

22. Il'in I.A. O russkom natsionalizme. M., 2006. $150 \mathrm{~s}$.

23. Berdyaev N.A. Koshmar zlogo dobra (O knige I. Il'ina «O soprotivlenii zlu siloyu») // Put'. Organ russkoi religioznoi mysli. № 4. Iyun'-iyul' 1926. M., 1992. S. 462-474.

24. Prilenskii V.I. Opyt issledovaniya mirovozzreniya rannikh russkikh liberalov. Ch. 1. M.: IFRAN, 1995. $311 \mathrm{s.}$

25. Leontovich V.V. Istoriya liberalizma v Rossii. 1762-1914. M., 1995. 548 s. 